\title{
Characterization of a New Virus from Garlic (Allium sativum L.), Garlic Mite-borne Mosaic Virus
}

\author{
Kazuo YAMASHITA*, Junichi SAKAI** and Kaoru HANADA**
}

\begin{abstract}
Flexuous, filamentous virus particles with a length of 700-800 nm were detected in garlic (Allium sativum L.) plants showing mosaic symptoms. The virus was sap-transmissible from garlic plants to seven out of 25 plant species tested, inducing local lesions on Chenopodium murale and Gomphrena globosa and a systemic mosaic on garlic. This virus was transmitted by the eriophyid mite, Aceria tulipae Keifer, but not by aphids. Two polypeptides with M.W. $30 \mathrm{kDa}$ and $28.5 \mathrm{kDa}$ were detected by SDS-PAGE of the purified virus preparation. The virus exhibited no serological relationships with leek yellow stripe, onion yellow dwarf or garlic latent viruses. No cytoplasmic cylindrical inclusions were observed in infected leaf cells of garlic or C. murale. The 3 'terminal nucleotide sequence of $2518 \mathrm{bp}$ was determined. It contained three putative open reading frames (ORFs) for $40 \mathrm{kDa}, 28 \mathrm{kDa}$ (a putative coat protein, $\mathrm{CP}$ ) and $15 \mathrm{kDa}$ polypeptides. The arrangement and amino acid sequences of these ORFs show close similarities with those of shallot virus $\mathrm{X}$ and garlic virus $(\mathrm{GV})-\mathrm{A},-\mathrm{B},-\mathrm{C}$ and $-\mathrm{D}$. The putative $\mathrm{CP}$ of the mite-borne virus has $98 \%$ amino acid sequence homology with $\mathrm{CP}$ of $\mathrm{GV}-\mathrm{C}$, but only $60-67 \%$ identity with $\mathrm{CPs}$ of four other viruses, indicating the classification of the mite-borne virus and GV-C as the same virus. We propose the name garlic mite-borne mosaic virus (GMbMV) for the virus.
\end{abstract}

(Received March 7, 1996 ; Accepted July 25, 1996)

Key words : garlic, garlic mite-borne mosaic virus, mite-transmitted virus.

\section{INTRODUCTION}

A number of virus diseases and viruses of garlic (Allium sativum) have been described ${ }^{28-30}$. Garlic latent carlavirus $(\mathrm{GLV})^{16)}$ and a potyvirus, designated as garlic mosaic potyvirus $(\mathrm{GMV})^{1,16,24)}$, have been reported to infect garlic in Japan. However, van Dijk ${ }^{29)}$ reported that GMV in Japan is possibly a complex of three distinct filamentous viruses-onion yellow dwarf potyvirus $(\mathrm{OYDV})^{2,6)}$, leek yellow stripe potyvirus (LYSV) ${ }^{2}$ and the garlic strain of onion mite-borne latent rymovirus $(\mathrm{OMbLV}-\mathrm{G})^{30)}$. We recently reported that LYSV isolated from garlic is closely related to GMV by biological and serological tests ${ }^{34}$. In addition, Iwai et al. ${ }^{11)}$ detected OYDV from Japanese garlic by ELISA tests. However, OMbLV-G has not been detected in garlic in Japan.

Recent reports based on nucleotide sequence analyses revealed the presence of novel filamentous viruses in commercial.garlic in Japan ${ }^{27)}$ and shallots in Russia ${ }^{31}$. The novel filamentous virus reported as shallot virus $\mathrm{X}$ $(\mathrm{SVX})^{31)}$ was serologically distinct from OYDV and shallot latent carlavirus (SLV), and did not produce granular inclusion bodies in infected plant tissues. The complete nucleotide sequence of SVX has also been reported $^{12)}$. Four different viral cDNAs derived from purified preparations of garlic plants with mixed infections were designated as garlic virus (GV)-A, - B, - C, and $-\mathrm{D}^{27}$. GV-A, $-\mathrm{B},-\mathrm{C}$ and $-\mathrm{D}$ were not isolated from the infected garlic plants by single-lesion transfer, and their biological and serological properties are unknown. The 3 '-terminal gene organization of SVX, GV-A, -B, -C and -D are similar, but different from those of other classified filamentous viruses, suggesting they form a new virus group.

We found that a mosaic disease of garlic prevalent in Aomori Prefecture, Japan, was easily transmitted by the eriophyid mite (Aceria tulipae Keifer), and was associated with flexuous filamentous virus particles ${ }^{33)}$. In this paper, we report the biological, physico-chemical, serological, cytopathological and molecular characteristics of the mite-borne virus isolated from garlic, which led us to the conclusion that the virus belongs to a new virus group.

\section{MATERIALS AND METHODS}

Source of a mite-borne virus. A garlic (Allium sativum cv. Fukuchi-howaito) plant showing mosaic symptoms was collected from a field located in Aomori

* Aomori Green BioCenter, Nogi, Aomori 030-01, Japan 
Prefecture in 1991. The virus was originally isolated by eriophyid mite transmission from a diseased garlic bulb to virus-free garlic plants. The virus was then transferred from infected garlic plants to Chenopodium murale by sap inoculation. After three successive single-lesion passages on $C$. murale, the virus was back-inoculated to virus-free garlic plants.

Mechanical inoculation tests. Infected garlic or C. murale leaf tissue was homogenized in $0.05 \mathrm{M}$ borate buffer (BB), pH 8.5, containing $10 \mathrm{mM}$ EDTA, and used to inoculate 25 different species of plants. Six of replicates were used for each species and two different experiments were done. Inoculated plants were maintained in a greenhouse at $18-24^{\circ} \mathrm{C}$ and symptoms were observed for six weeks after inoculation. Symptomless plants were back-inoculated to $C$. murale by sap inoculation.

Mite and aphid transmission tests. Eggs of eriophyid mites (A. tulipae) collected from garlic were transferred onto Welsh onion (A. fistulosum) seedlings. After hatching, their non-viruliferous first-instar nymphs were transferred and maintained on Welsh onion seedlings. Mites at different growth stages were allowed an acquisition feeding period of $24 \mathrm{hr}$ on infected garlic leaves and an inoculation access period of $24 \mathrm{hr}$ on virus-free garlic bulbs. Following test periods, the mites were killed by dipping into the insecticide Pirimiphosmethyl. Aphids, Acyrthosiphon solani and Myzus persicae, were starved for $2 \mathrm{hr}$, and then allowed an acquisition feeding period of 10-15 min on infected garlic plants and an inoculation access period of $1 \mathrm{hr}$ on virus-free garlic plants. Following test periods, the aphids were killed by spraying the insecticide DDVP. Transmission tests with mites and aphids were done in a greenhouse using five mites or ten aphids per virus-free plant. Inoculated plants were maintained for three months to observe symptoms. Symptomless plants were backinoculated to $C$. murale by sap inoculation.

Virus purification. Two to three months after inoculation, infected fresh garlic leaves were homogenized in a Waring blender for 5 min with 6 volumes (v/ w) of $0.5 \mathrm{M} \mathrm{BB}, \mathrm{pH} 8.5$, containing $10 \mathrm{mM}$ EDTA and $0.2 \%(\mathrm{v} / \mathrm{v})$ thioglycolic acid, and then mixed with $10 \%$ $(\mathrm{v} / \mathrm{v})$ carbon tetrachloride. After centrifugation of the homogenate at $7000 \times g$ for $10 \mathrm{~min}, 1 \%(\mathrm{v} / \mathrm{v})$ Triton $\mathrm{X}-100,5 \%(\mathrm{w} / \mathrm{v})$ polyethylene glycol (mol. wt. 6000) and $0.1 \mathrm{M} \mathrm{NaCl}$ was added to the aqueous phase. After stirring for $1 \mathrm{hr}$ at $4^{\circ} \mathrm{C}$, the suspension was centrifuged at $7000 \times g$ for $10 \mathrm{~min}$. The pellet was resuspended in one-fifth the original volume of the extract in a solution of $0.05 \mathrm{M} \mathrm{BB}, \mathrm{pH} 8.3,0.5 \mathrm{M}$ urea and $10 \mathrm{mM}$ EDTA (suspending buffer), then stirred gently for $1 \mathrm{hr}$. After two cycles of differential centrifugation $(7000 \times g$ for 10 $\min$, and $170,000 \times g$ for $1.5 \mathrm{hr}$ ), the virus was further purified by equilibrium density gradient centrifugation $(215,000 \times g$ for $3.5 \mathrm{hr}$ in Hitachi P65NT roter) in a $\mathrm{CsCl}$ solution, using an initial concentration $36.7 \%(\mathrm{w} / \mathrm{v})$ in the suspending buffer. The virus zone was collected and pelleted by centrifugation at $170,000 \times g$ for $1.5 \mathrm{hr}$. The pellet was resuspended in $2 \mathrm{ml}$ of $0.02 \mathrm{M} \mathrm{BB}, \mathrm{pH} 8.0$ containing $5 \mathrm{mM}$ EDTA. After a low speed centrifugation $(7000 \times g$ for $10 \mathrm{~min})$, supernatant was collected as a purified virus preparation.

Electron microscopy. Leaf extracts and purified virus preparations were observed after negative staining with $1 \%$ phosphotungstic acid in distilled water, $\mathrm{pH} 7.0$, by Hitachi electron microscope H-7000. For ultra-thin sectioning, tissue samples of the virus-infected garlic and $C$. murale plants were fixed in $2 \%$ glutaraldehyde in $0.1 \mathrm{M}$ phosphate buffer, $\mathrm{pH} 7.0$ (PB), for $4 \mathrm{hr}$, followed by post-fixation in $1 \%$ osmium tetroxide in $0.1 \mathrm{M}$ PB for 3 hr at $4^{\circ} \mathrm{C}$. After a dehydration series with $50-100 \%$ ethanol, the tissues were embedded in Spurr's resin. Thin sections were double-stained with uranyl acetate and lead citrate.

Serology. Purified viruses $(0.5 \mathrm{mg})$ were emulsified with Freund's complete adjuvant (DIFCO Laboratories) (1:1) and intramuscularly injected into a rabbit three times at weekly intervals, followed by two intravenous injections at bi-weekly intervals. The rabbit was bled 2 weeks after the final injection. Antisera to OYDV (supplied by Dr. M. Kameya-Iwaki, Yamaguchi University), LYSV (Dr. T. Maeda, Research Institute for Bioresources, Okayama University), and GLV (Dr. I. Sako, Tottori Fruit, Vegetable and Ornamental Crop Experiment Station) were also used for serological tests. Serological properties were examined by leaf dip serology as described by Langenberg ${ }^{15}$, and by double immunodiffusion tests using $0.7 \%$ Difco noble agarose gel in $0.1 \mathrm{M} \mathrm{PB}, \mathrm{pH} 7.0$, containing $0.5 \%$ sodium dodecyl sulfate (SDS) and $0.05 \%$ sodium azide.

SDS-PAGE and Western blotting. The molecular weight of the coat protein $(\mathrm{CP})$ from purified viruses was determined by SDS-polyacrylamide gel electrophoresis (PAGE) $(12.5 \% \text { slab gel })^{14}$. After electrophoresis, the gel was stained with $0.1 \%$ Coomassie brilliant blue. After proteins were transferred onto nitrocellulose (BIO-RAD Laboratories, Inc.), viral proteins were detected by enzyme-linked immunostaining as described by Shirako and Ehara ${ }^{25)}$ using virus-antiserum diluted with $20 \mathrm{mM}$ Tris- $\mathrm{HCl}$ buffer (TBST), (0.15 M NaCl, $0.05 \% \mathrm{NaN}_{3}, \mathrm{pH} 7.5$, and $0.02 \%$ Tween 20) at $1: 4000$ and alkaline phosphatase-conjugated anti-rabbit goat immunoglobulin G (Sigma Chemical Company) diluted with TBST at $1: 2000$.

RNA extraction and cDNA cloning. Viral RNA was extracted from purified viruses using proteinase $\mathrm{K}$ and SDS followed by phenol extraction and ethanol precipitation. The molecular weight of viral RNA was estimated by $0.8 \%$ agarose gel electrophoresis under denaturing conditions with $2.2 \mathrm{M}$ formaldehyde. cDNA synthesis was carried out with the cDNA Synthesis System Plus kit (Amersham International plc) according to the manufacturer's instructions, using oligo (dT) as a primer. The cDNA was ligated EcoRV-cut pBluescript II SK ${ }^{+}$. Competent Escherichia coli JM109 
cells were transformed with the ligated plasmid.

Nucleotide sequence analysis. Five CDNA clones were examined by southern blot hybridization with a viral RNA probe using the ECL direct nucleic acid labelling and detection system (Amersham International plc). The largest cDNA clone, pGMM88 (2.5 kb), was selected and sequenced by the dideoxynucleotide chain termination method using $\Lambda \mathrm{BI}$ sequencer $373 \mathrm{~A}$. The entire cDNA insert was sequenced in both orientations. Sequences were analyzed by the DNASIS program (Hitachi).

\section{RESULTS}

\section{Host range and symptomatology}

Based on symptom development, and back-inoculation tests, the virus was transmitted by mechanical inoculation to seven plant species from two families out of the 25 species from eight families tested. Chlorotic local lesions were induced on $C$. murale 2 to 4 weeks after inoculation (Fig. 1B). Mosaic symptoms were produced systemically on garlic (Allium sativum). A few local lesions with chlorotic centers and red edges were

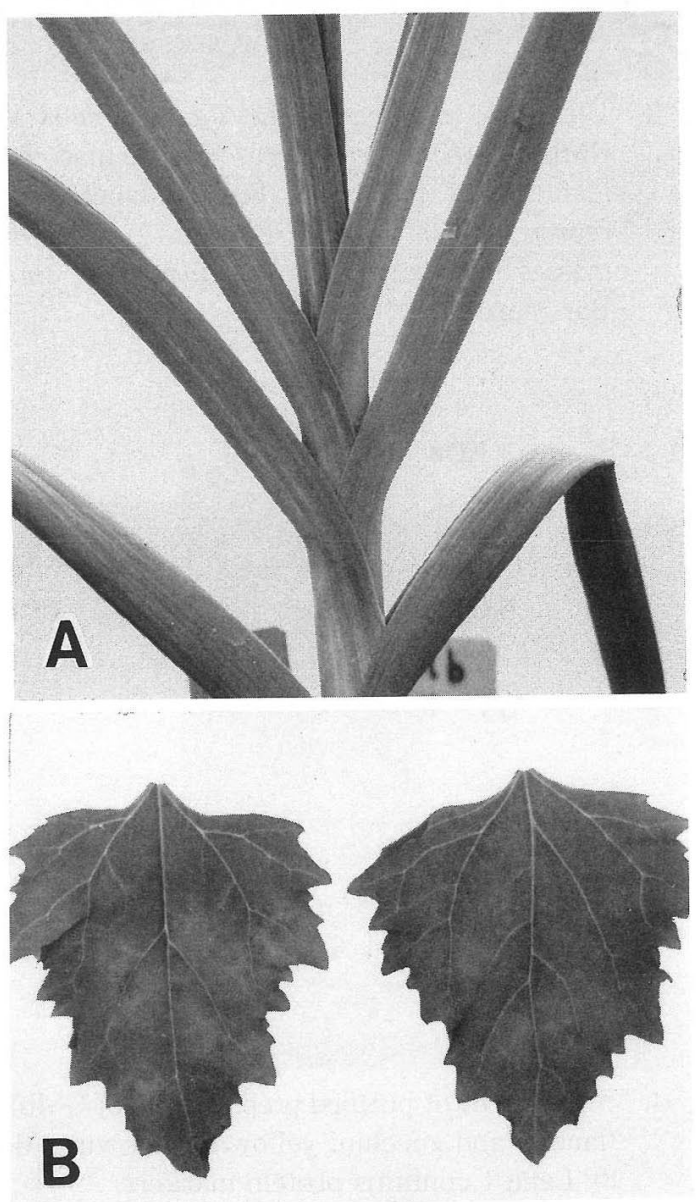

Fig. 1. Symptoms after mechanical inoculation with GMbMV. (A) Mosaic symptoms on systemically infected garlic cv. Fukuchi-howaito. (B) Chlorotic local lesions on inoculated leaves of Chenopodium murale. produced on inoculated leaves of Gomphrena globosa. Local latent infection occurred on C. amaranticolor and C. quinoa, whereas systemic latent infection occurred in leek (A. ampeloprasum var. porrum cv. Wander) and Tetragonia expansa.

No infection was detected in Allium cepa, A. fistulosum, Amaranthus tricolor, Beta vulgaris, Brassica campestris, B. napus, Celosia cristata, Cucumis sativum cv. Suyo, Cucurbita pepo, Datura stramonium, Lycopercicon esculentum cv. Kyoryokubeiju, Nicotiana clevelandii, $N$. debneyi, $N$. glutinosa, N. occidentalis, N. rustica, N. tabacum cv. White Burley, Petunia hybrida, Phaseolus vulgaris cv. Top Crop, Pisum sativum cv. Kinusaya, Vicia faba cv. Uchikoshiissun, Vigna sesquipedalis cv. Kurotanesanjaku.

\section{Eriophyid mite and aphid transmission}

The virus was easily transmitted from garlic to garlic by second-instar nymphs and adults of $A$. tulipae (Table 1); Virus-infected garlic plants showed mild mosaic symptoms about two months after inoculation. However, none of the 10 garlic plants inoculated with the aphids $A$. solani or $M$. persicae were infected with the virus.

\section{Physical properties}

In crude extracts of infected garlic leaves, the virus kept its infectivity to $C$. murale after diluting to $10^{-3}$ but not to $10^{-4}$, after heating for $10 \mathrm{~min}$ at $65^{\circ} \mathrm{C}$ but not at $70^{\circ} \mathrm{C}$, and after incubating the crude extracts at $24^{\circ} \mathrm{C}$ for 3 days but not for 5 days (data not shown).

\section{Electron microscopy}

Leaf-dip preparations from infected $C$. murale plants contained flexuous filamentous particles (Fig. 2A). These particles, ranging in length from 700 to $800 \mathrm{~nm}$ and averaging $716 \mathrm{~nm}$, were dispersed or clustered in the cytoplasm of mesophyll cells of garlic (Fig. 3A) and C. murale (Fig. 3B). No cylindrical inclusions were observed in any cells of infected garlic or C. murale plants.

\section{Purification}

Yields of purified virus particles ranged from 0.8 to 1.5 mg per $100 \mathrm{~g}$ of garlic leaves. Many particles longer than the unit-length, formed by end-to-end aggregation, were observed by electron microscopy (Fig. 2B). The purified preparation showed a UV absorption spectrum characteristic of nucleoprotein with the absorption maximum at $260 \mathrm{~nm}$ and the minimum at $246 \mathrm{~nm}$. The ratios of $A_{260 / 280}$ and $A_{\max / m i n}$ were 1.22 and 1.11 , respectively.

Table 1. Results of transmission tests of garlic miteborne mosaic virus (GMbMV) by three stages of eriophyid mite (Aceria tulipae)

\begin{tabular}{lcc}
\hline \hline Stages of mite & $\begin{array}{c}\text { Number of plants } \\
\text { transmitted/ } \\
\text { inoculated }\end{array}$ & Proportions \\
\hline First-instar nymph & $2 / 40$ & 0.05 \\
Second-instar nymph & $23 / 48$ & 0.48 \\
Adult & $41 / 66$ & 0.62 \\
\hline
\end{tabular}




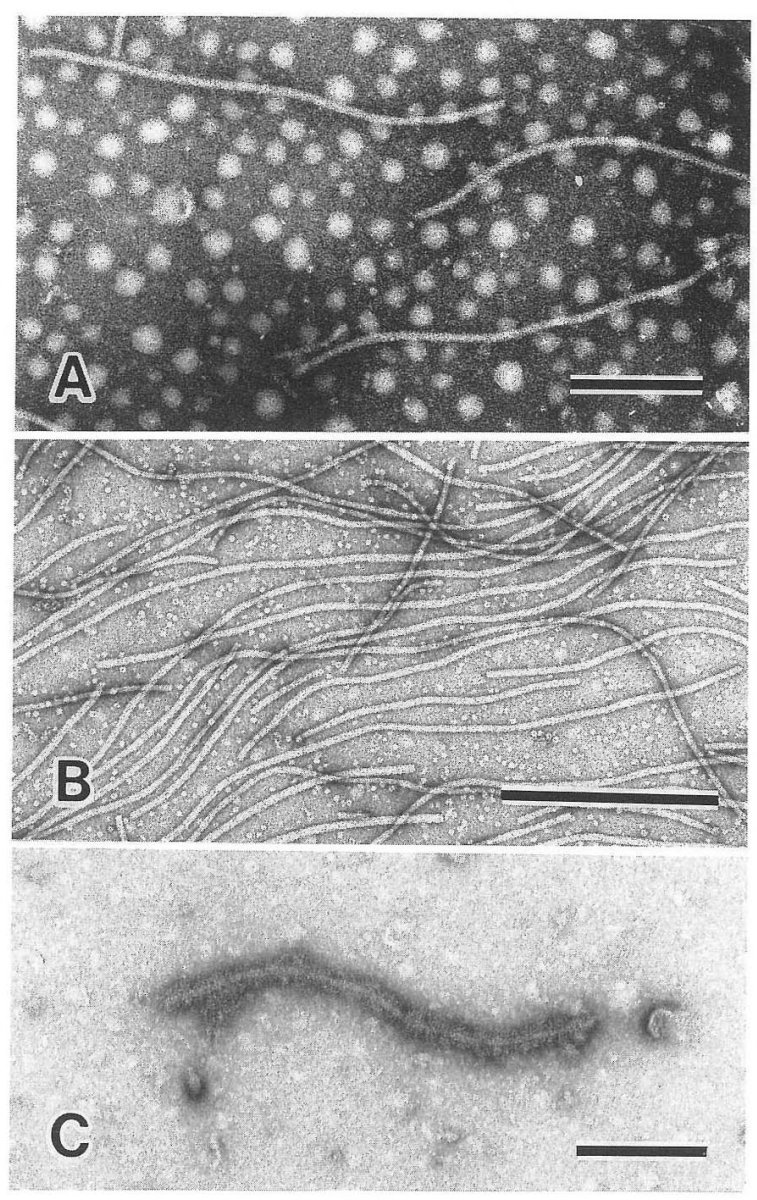

Fig. 2. Particles of GMbMV negatively stained with $2 \%$ PTA. (A) Particles in sap of Chenopodium murale. Bar represents $200 \mathrm{~nm}$. (B) Particles in a purified virus preparation. Bar represents 500 $\mathrm{nm}$. (C) A leaf dip preparation incubated with a 1/50 dilution of antiserum to GMbMV for 15 min before negative staining. Bar represents 200 nm.

\section{Serology}

The antiserum to the virus had a titer of $1 / 512$ against the homologous virus preparation in microprecipitin tests. In double immunodiffusion tests, the purified virus preparation reacted with the homologous antiserum, but not with antisera to OYDV, LYSV or GLV (data not shown). After leaf-dip serology, the virus particles were decorated with the homologous antiserum (Fig. 2C), but not with the other antisera.

\section{SDS-PAGE}

Using SDS-PAGE of the purified virus preparation (Fig. 4), two major polypeptide bands were detected and estimated to have molecular weights of $30 \mathrm{kDa}$ and 28.5 $\mathrm{kDa}$. Both polypeptides reacted with the virus antiserum during Western blotting (data not shown). The $28.5 \mathrm{kDa}$ component is considered to be a breakdown product derived from the $30 \mathrm{kDa}$ component by proteolytic cleavage during purification, as found for other filamentous viruses ${ }^{4,10,12)}$.

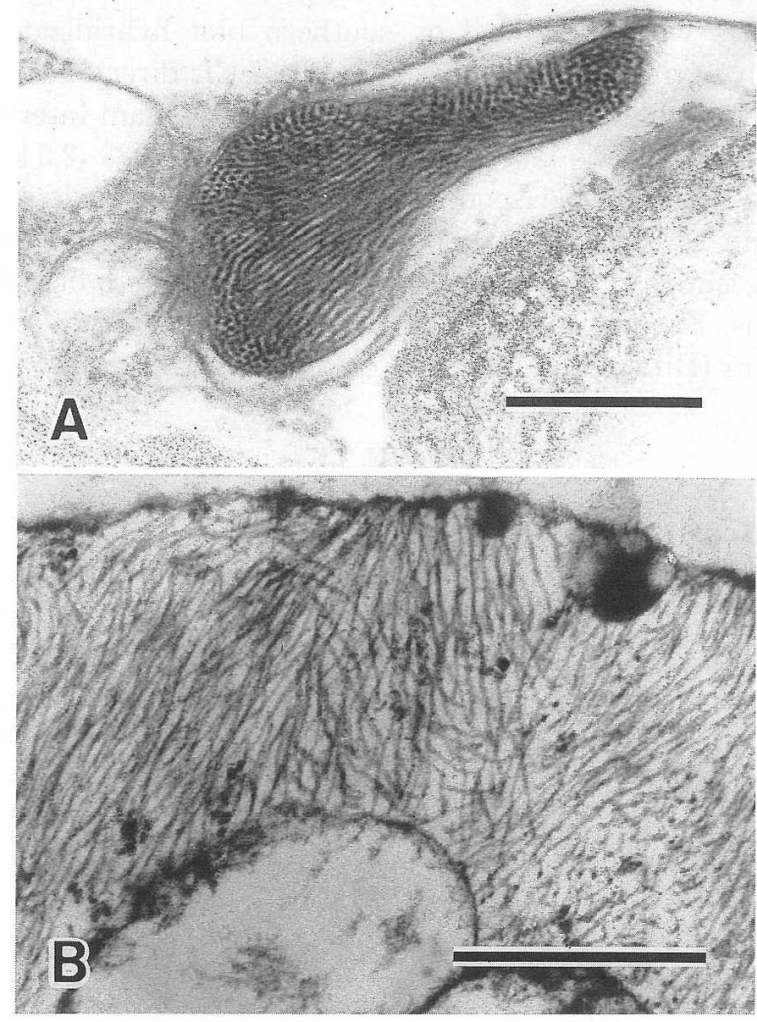

Fig. 3. Ultrathin sections of the infected cells with GMbMV. (A) Fibrous virus particle masses in a leaf cell of garlic cv. Fukuchi-howaito. Bar represents $500 \mathrm{~nm}$. (B) Fibrous virus particle masses in a leaf cell of Chenopodium murale. Bar represents $500 \mathrm{~nm}$.

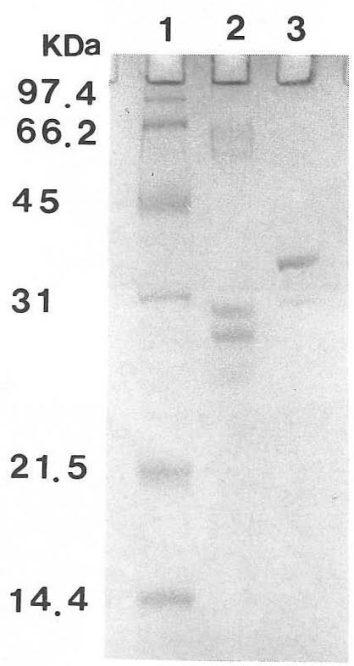

Fig. 4. SDS-PAGE of purified preparations of GMbMV (lane 2) and zucchini yellow mosaic virus (lane 3). Lane 1 contains protein markers.

\section{Nucleotide sequence}

The length of viral RNA was about $10 \mathrm{~kb}$ as determined by agarose gel electrophoresis. All the examined 

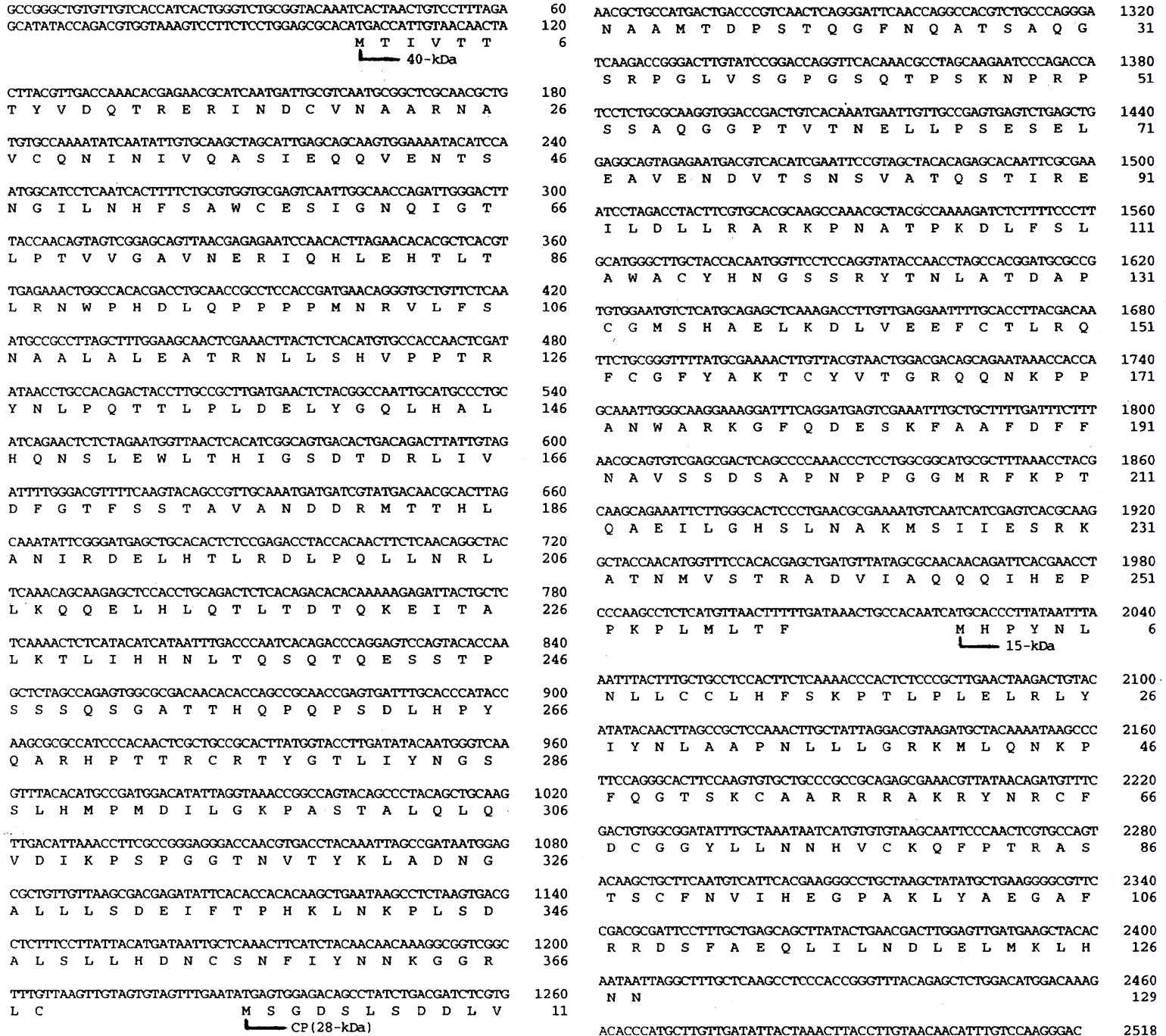

Fig. 5. The sequence of the $3^{\prime}$-terminal 2518 nucleotides of GMbMV RNA. Predicted amino acid sequences of the $40 \mathrm{kDa}$, $28 \mathrm{kDa}$ (a putative coat protein) and $15 \mathrm{kDa}$ proteins are shown.

cDNA clones hybridized specifically with the viral RNA probe (data not shown). The nucleotide sequence of the $3^{\prime}$-terminal 2518 nucleotides of the virus genome was determined from the largest clone pGMM88 (Fig. 5). The sequence has been deposited in the GSDB, DDBJ, EMBL and NCBI database with the accession number D49443. Analysis of the sequence gave three open reading frames (ORFs) in the positive strand (Fig. 5). The arrangement of these three ORFs showed close similarities with those of SVX ${ }^{12)}$, GV-A, GV-B, GV-C and GV-D ${ }^{27)}$ (Fig. 5). The first ORF coded for an unkown protein with a calculated molecular weight of 40,960 Da $(40 \mathrm{kDa})$.

The second ORF coded for a putative coat protein (CP) with a calculated molecular weight of $27,978 \mathrm{Da}(28$ $\mathrm{kDa})$. This protein showed high amino acid sequence homology $(60-98 \%)$ with the CPS of $\mathrm{SVX}^{12)}$, GV-A, GV-B, GV-C and GV-D ${ }^{27)}$ (Table 2). (The sequences of GV-B, GV-C, and GV-D with the DDBJ accession numbers D11158, D11159, and D11160, respectively, have been corrected, 'Sumi, S. personal comm.) However, it showed only weak homology (28-33\%) with the CPs of nine filamentous viruses; potato virus $\mathrm{X}^{22)}$ and narcissus mosaic potexviruses ${ }^{36)}$, poplar mosaic ${ }^{8)}$, potato virus $\mathrm{S}^{17)}$ and GV1 carlaviruses ${ }^{19)}$, potato virus $\mathrm{Y}^{23)}$ and $\mathrm{GV} 2$ potyviruses $^{19)}$, wheat streak mosaic rymovirus ${ }^{20)}$, and barley yellow mosaic bymovirus ${ }^{13)}$ (Table 2).

The third ORF coded for a protein with a calculated molecular weight of $14,775 \mathrm{Da}(15 \mathrm{kDa})$. This $15 \mathrm{kDa}$ protein contained the putative zinc finger domain $\mathrm{CX}_{2} \mathrm{CX}_{7} \mathrm{HXC}$, where $\mathrm{X}$ is any amino acid, (at position 2215-2256) like the analogous proteins of other carlaviruses $^{7}$. This protein showed $99 \%$ amino acid sequence homology with the $15 \mathrm{kDa}$ protein of $\mathrm{GV}-\mathrm{C}^{27)}$ (Table 2).

The $3^{\prime}$ non-coding region of the mite-borne virus showed high nucleotide sequence homology (81-100\%) with the corresponding regions of $\mathrm{SVX}^{12)}, \mathrm{GV}-\mathrm{A}, \mathrm{GV}-\mathrm{B}$, GV-C and GV-D ${ }^{27)}$ (Table 2).

\section{DISCUSSION}

A number of filamentous viruses have been reported in garlic and other Allium species in many countries. They 
Table 2. Percent amino acid or nucleotide sequence homology between 3 ORF products and $3^{\prime}$ non-coding regions of GMbMV and other filamentous viruses ${ }^{\text {a) }}$

\begin{tabular}{lcccc}
\hline \multirow{2}{*}{ Viruses } & \multicolumn{4}{c}{ GMbMV } \\
\cline { 2 - 5 } & $40 \mathrm{kDa}$ & $\mathrm{CP}$ & $15 \mathrm{kDa}$ & $3^{\prime} \mathrm{NCR}$ \\
\hline GV-A & $41^{\mathrm{b})}$ & 62 & 58 & 82 \\
GV-B & 43 & 67 & 66 & 87 \\
GV-C & - & 98 & 99 & 100 \\
GV-D & - & 61 & 52 & 81 \\
SVX & 40 & 60 & 63 & 76 \\
GV-1 & - & 31 & 28 & 42 \\
GV-2 & - & 28 & - & 18 \\
PVS & - & 29 & 27 & 53 \\
\hline
\end{tabular}

a) The sources of sequence data were: GMbMV (this paper), GV-A, -B, -C and - ${ }^{27)}, \mathrm{SVX}^{12)} \mathrm{GV}-1$ and $-2^{19)}$ and $\mathrm{PVS}^{17)}$.

b) The amino acid sequences of the $40 \mathrm{kDa}, \mathrm{CP}$ and $15 \mathrm{kDa}$ proteins of GMbMV and the nucleotide sequence of its $3^{\prime}$ non-coding region $\left(3^{\prime} \mathrm{NCR}\right)$ were compared with those of corresponding proteins or regions of other viruses by the MAXIMUM MATCHING program of DNASIS.

were classified mainly into two aphid-borne virus groups-LYSV ${ }^{2,18,21,34)}$ and OYDV ${ }^{2,6,11,29)}$, belonging to the genus Potyvirus; and carnation latent virus ${ }^{5)}$, GLV ${ }^{16)}$, garlic common latent virus ${ }^{28)}$ and $\mathrm{SLV}^{3,28)}$, belonging to Carlavirus. The virus examined in this study showed no serological relationship to OYDV, LYSV or GLV. The virus was easily transmitted by the eriophyid mite, but not by aphids. No cytoplasmic inclusion body commonly observed in the family Potyviridae ${ }^{9}$ was detectable in the mite-borne virus-infected plants. Thus, the mite-borne virus differs clearly from potyviruses and carlaviruses.

The mite-borne virus resembles the garlic strain of OMbLV $-G^{30)}$ in host range, vector relationships and particle morphology. However, they differ in their cytopathological characteristics. The garlic strain of $\mathrm{OMbLV}$ induces cylindrical inclusions in the cytoplasm of infected leaf cells ${ }^{30)}$, whereas the mite-borne virus does not. The mite-borne virus is related to SVX, which also does not induce inclusion bodies in its shallot plant host ${ }^{31}$.

The CP of the mite-borne virus migrates during SDSPAGE as a $30 \mathrm{kDa}$ protein, although its molecular weight was calculated as $28 \mathrm{kDa}$ from its deduced amino acid sequence. The same results have been reported for the $\mathrm{CP}$ of $\mathrm{SVX}^{12)}$. The ORF5-28 $\mathrm{kDa}$ protein of SVX migrated as a $32-36 \mathrm{kDa}$, perhaps because of its high hydrophilicity as indicated by its amino acid sequence.

The 3 '-terminal gene organization of the mite-borne virus is quite similar to those of SVX and GV-A, - B, -C and -D. Their genome organizations are apparently different from those of filamentous viruses, potyviruses $^{26,32)}$ and rymoviruses ${ }^{20,35)}$, carlaviruses ${ }^{7,8,17)}$ and potexviruses ${ }^{22,36)}$, demonstrating that a new virus group needs to be established to accommodate them.
The amino acid sequences of the $\mathrm{CP}$ and $15 \mathrm{kDa}$ proteins of the mite-borne virus and GV-C showed $98 \%$ and $100 \%$ homology, respectively, and the entire nucleotide sequences of their $3^{\prime}$ non-coding regions are $100 \%$ identical. Thus, they should be classified as the same virus.

We propose the name 'garlic mite-borne mosaic virus (GMbMV)' for the virus characterized in this study. Further investigations are need to clarify its relationships to SVX, GV-A, -B, and -D.

The authors wish to thank Drs. M. Kameya-Iwaki, T. Maeda, and I. Sako for supplying antisera ; Dr. G. I. Mink, Washington State University, for critical reading of the manuscript; and Dr. T. Sano and Mr. T. Fujita, Faculty of Agriculture, Hirosaki University and Dr. S. Naito, Tohoku National Agricultural Experiment Station for their kind help.

\section{Literature cited}

1. Abiko, K., Watanabe, Y. and Nishi, Y. (1980). Studies on garlic mosaic. I. Causal virus. Bull. Veg. \& Ornam. Crops Res. Stn. Japan, Ser. A, No. $7: 139-147$ (in Japanese).

2. Bos, L., Huijberts, N., Huttinga, H. and Maat, D.Z. (1978). Leek yellow stripe virus and its relationships to onion yellow dwarf virus; characterization, ecology and possible control. Neth. J. Plant Pathol. 84 : 185-204.

3. Bos, L., Huttinga, H. and Maat, D.Z. (1978). Shallot latent virus, a new carlavirus. Neth. J. Plant Pathol. 84 : 227-237.

4. Brakke, M.K., Skopp, R.N. and Lane, L.C. (1990). Degradation of wheat streak mosaic virus capsid protein during leaf senescence. Phytopathology 80 : 14011405.

5. Conci, V. and Nome, S.F. (1992). Filamentous viruses of garlic in Argentina. Plant Dis. 76 : 594-596.

6. Delecolle, B. and Lot, H. (1981). Garlic viruses: Detection and partial characterization with immune electron microscopy of three viruses in different garlic populations with mosaic. Agronomie 1:763-770.

7. Haylor, M.T.M., Brunt, A.A. and Coutts, R.H.A. (1990). Conservation of the $3^{\prime}$ terminal nucleotide sequence in five carlaviruses. Nucleic Acids Res. 18:6127.

8. Henderson, J., Gibbs, M.J., Edwards, M.L., Clarke, V.A., Gardner, K.A. and Cooper, J.I. (1992). Partial nucleotide sequence of poplar mosaic virus RNA confirms its classification as a carlavirus. J. Gen. Virol. 73 : 18871890.

9. Hollings, M. and Brunt, A.A. (1981). Potyvirus group. CMI/AAB Descriptions of Plant Viruses, No. 245.

10. Huttinga, H. and Mosch, W.H.M. (1974). Properties of viruses of the potyvirus group. 2. Buoyant density, S value, particle morphology, and molecular weight of the coat protein subunit of bean yellow mosaic virus, pea mosaic virus, lettuce mosaic virus, and potato virus $\mathrm{Y}^{\mathrm{N}}$. Neth. J. Plant Pathol. $80: 19-27$.

11. Iwai, H., Mitsushima, T., Etoh, T. and Arai, K. (1990). Detection of two viruses from garlic clones by ELISA. Mem. Fac. Agric. Kagoshima Univ. 40 : 1-7 (in Japanese 
with English summary).

12. Kanyuka, K.V., Vishichenko, V.K., Levay, K.E., Kondrikov, D.Yu., Ryabov, E.V. and Zavriev, S.K. (1992). Nucleotide sequence of shallot virus X RNA reveals a $5^{\prime}$-proximal cistron closely related to those of potexviruses and a unique arrangement of the $3^{\prime}$-proximal cistrons. J. Gen. Virol. 73 : 2553-2560.

13. Kashiwazaki, S., Minobe, Y., Omura, T. and Hibino, H. (1990). Nucleotide sequence of barley yellow mosaic virus RNA1: A close evolutionary relationship with potyviruses. J. Gen. Virol. $71: 2781-2790$.

14. Laemmli, U.K. (1970). Cleavage of structural proteins during the assembly of the head of bacteriophage T4. Nature $227: 680-685$.

15. Langenberg, W.G. (1974). Leaf-dip serology for the determination of strain relationships of elongated plant viruses. Phytopathology 64 : 128-131.

16. Lee, W., Yamazaki, S., Osaki, T. and Inouye, T. (1979). Two elongated viruses in garlic, garlic latent virus and garlic mosaic virus. Ann. Phytopathol. Soc. Jpn. 45 : 727-734 (in Japanese with English summary).

17. Mackenzie, D., Tremaine, J.H. and Stace-Smith, R. (1989). Organization and interviral homologies of the 3 'terminal portion of potato virus S RNA. J. Gen. Virol. $70: 1053-1063$.

18. Mohamed, N.A. and Young, B.R. (1990). Leek yellow stripe virus in New Zealand. N.Z. J. Agric. Res. 23 : 129 131.

19. Nagakubo, T., Kubo, M. and Oeda, K. (1994). Nucleotide sequences of the $3^{\prime}$ regions of two major viruses from mosaic-diseased garlic: Molecular evidence of mixed infection by a potyvirus and a carlavirus. Phytopathology 84 : 640-645.

20. Niblett, C.L., Zagula, K.R., Calvert, L.A., Kendall, T.L., Stark, D.M., Smith, C.E., Beachy, R.N. and Lommel, S.A. (1991). cDNA cloning and nucleotide sequence of the wheat streak mosaic virus capsid protein gene. J. Gen. Virol. 72 : 499-504.

21. Noda, C. and Inouye, N. (1989). Leek yellow stripe virus isolated from an ornamental Allium plant in Japan. Ann. Phytopathol. Soc. Jpn. 55 : 208-215.

22. Querci, M., van der Vlugt, R., Goldbach, R. and Salazar, L.F. (1993). RNA sequence of potato virus X strain HB. J. Gen. Virol. $74: 2251-2255$.

23. Robaglia, C., Durand-Tardif, M., Tronchet, M., Boudazin, G., Astier-Manifacier, S. and Casse-Delbart, F. (1989). Nucleotide sequence of potato virus Y (N strain) genomic RNA. J. Gen. Virol. 70 : 935-947.

24. Sako, N. (1976). Virus disease in garlic. Ann. Phytopathol. Soc. Jpn. $42: 384$ (Abstr. in Japanese).

25. Shirako, Y. and Ehara, Y. (1986). Rapid diagnosis of Chinese yam necrotic mosaic virus infection by electroblot immunoassay. Ann. Phytopathol. Soc. Jpn. 52 : 453459.

26. Shukla, D.D. and Ward, C.W. (1989). Structure of potyvirus coat proteins and its application in the taxonomy of the potyvirus group. Adv. Virus Res. 36 : 273-314.

27. Sumi, S., Tsuneyoshi, T. and Furutani, H. (1993). Novel rod-shaped viruses isolated from garlic, Allium sativum, possessing a unique genome organization. J. Gen. Virol. $74: 1879-1885$.
28. van Dijk, P. (1993). Carlavirus isolates from cultivated Allium species represent three viruses. Neth. J. Plant Pathol. 99 : 233-257.

29. van Dijk, P. (1993). Survey and characterization of potyviruses and their strains of Allium species. Neth. J. Plant Pathol. 99 Suppl. 2:1-48.

30. van Dijk, P., Verbeek, M. and Bos, L. (1991). Miteborne virus isolated from cultivated Allium species, and their classification into two new rymoviruses in the family Potyviridae. Neth. J. Plant Pathol. 97 : 381-399.

31. Vishnichenko, V.K., Konareva, T.N. and Zavriev, S.K. (1993). A new filamentous virus in shallot. Plant Pathol. $42: 121-126$.

32. Ward, C.W., McKern, N.M., Frenkel, M.J. and Shukla, D.D. (1992). In Potyvirus Taxonomy (Barnett, O.W., ed.) : Sequence data as the major criterion for potyvirus classification. Arch. Virol. (Suppl. 5), Springer-Verlag, New York, pp. 283-297.

33. Yamashita, K. (1992). Transmission of garlic mosaic virus by Aceria tulipae. Ann. Phytopathol. Soc. Jpn. 58 : 621 (Abstr. in Japanese).

34. Yamashita, K., Sakai, J. and Hanada, K. (1995). Leek yellow stripe virus (LYSV) isolated from garlic and its relationship to garlic mosaic virus (GMV). Ann. Phytopathol. Soc. Jpn. 61 : 273 (Abstr. in Japanese).

35. Zagula, K.R., Niblett, C.L., Robertson, N.L., French, R. and Lommel, S.A. (1992). In Potyvirus Taxonomy (Barnett, O.W., ed.): Potyviridae: genus Rymovirus. Arch. Virol. (Suppl. 5), Springer-Verlag, New York, pp. 269-276.

36. Zuidema, D., Linthorst, H.J.M., Huisma, M.J., Asjes, C.J. and Bol, J.F. (1989). Nucleotide sequence of narcissus mosaic virus RNA. J. Gen. Virol. 70 : 267-276.

\section{和 文 摘 要}

山下一夫・酒井淳一・花田 薰: ニンニクから分離された新 ウイルス，ニンニクダニ伝染モザイクウイルス

モザイク症状を呈するニンニク (Allium sativum L.) から長 さ 700〜800 nm のひも状ウイルスが分離された。本ウイルスは ニンニク打よびリーキに全身感染したほか, Chenopodium murale, C. quinoa およびセンニチコウなどに局部感染した。本 ウイルスはチューリップサビダニで伝搬されたが，アブラムシ では伝搬されなかった。純化ウイルスから, SDS-PAGEにより $30 \mathrm{kDa}$ 抢よび $28.5 \mathrm{kDa}$ のタンパク質が検出された。本ウイル スはリーキイエローストライプウイルス，ネギ萎縮ウイルスお よびニンニク潜在ウイルスの各抗血清には反応せず，二ンニク および C. murale の感染細胞内には細胞質封入体は観察されな かった。本ウイルスゲノム RNAの $3^{\prime}$ 末端から 2518 塩基の配 列を決定した。この領域は, $40 \mathrm{kDa}$ タンパク質, 外被タンパク 質と推定される $28 \mathrm{kDa}$ タンパク質および $15 \mathrm{kDa}$ タンパク質 をコードすると思われた。これらの遺伝子の配置および翻訳産

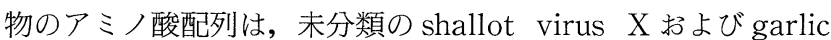
virus $(\mathrm{GV})-\mathrm{A},-\mathrm{B},-\mathrm{C},-\mathrm{D}$ と類似していた。 $28 \mathrm{kDa}$ タンパク質 のアミノ酸配列の相同性は, GV-C とは $98 \%$, 他の 4 種ウイルス とは 60〜 67\%であったことから，本ウイルスと GV-C は同種の ウイルスであると考えられた。本研究により性状が明らかにな ったウイルスを，ニンニクダニ伝染モザイクウイルス（garlic mite-borne mosaic virus: GMbMV) と命名するよう提案した w。 